\title{
The Parallel Link Between Economic Growth and the Growth of Government Spending: Wagner's Law Visited for Liberia: A Vector Error Correction Methodology
}

\author{
Lester Zomatic Tenny \\ The Graduate School of Business and Public Administration, MBA/MPA Program, University of Liberia, Monrovia, Liberia
}

\section{Email address:}

drltenny@nocal.com.lr

\section{To cite this article:}

Lester Zomatic Tenny. The Parallel Link Between Economic Growth and the Growth of Government Spending: Wagner's Law Visited for Liberia: A Vector Error Correction Methodology. International Journal of Business and Economics Research.

Vol. 9, No. 6, 2020, pp. 375-381. doi: 10.11648/j.ijber.20200906.12

Received: November 24, 2020; Accepted: December 9, 2020; Published: December 16, 2020

\begin{abstract}
The objective of this paper is to investigate the validity of Wagner's law within the context of whether it informs the growth of public expenditure for the periods 1970 to 2020 in Liberia. This study analyzed the link between economic growth, captured as Gross Domestic Product (GDP) and government spending in Liberia from 1970 to 2020 . The data collected was annual time series data from the World Development Indicator (WDI), Ministry of Finance and Development Planning of Liberia and the World Bank Group website. The data on GDP and government spending were used. Vector error correction (VEC) model which shows the presence of a cointegrating equation or the presence of a long run relationship between the growth of the macroeconomy and the growth of public spending in Liberia was adopted as the suitable methodology to conduct the study. Augmented DF test as well as Unit roots to test for stationarity was used. The author used the Johansen cointegration test to test for long run relationship in the economy. Normality test, Heteroskedasticity as well as LM serial correlation tests for diagnostics were applied. The result showed a strong link between economic growths, captured as GDP and government spending in Liberia over the studied periods and therefore showed that Wagner's Law is valid for the Liberian economy. There are several studies which show the link between the growth of the macroeconomy and the growth of (government spending) in several countries. There has never been any study on the link between these variables (GDP and Government spending) in Liberia. This study is the first of its kind and therefore contributes to the stockpile of existing literatures on Wagner's Law. The law which is a very significant law in the parlance of public finance is attributed to the Wagner when he observed the existence of a pattern between how economy growth relative to how the public envelop grows [15]. Wagner's observed a direct parallel relation between the two variables and concluded that the growth of the macroeconomy is directly associated with the growth of government expenditure.
\end{abstract}

Keywords: Wagner's Law, Government Expenditure, Economic Growth (GDP), Vector Error Correction Model

\section{Introduction}

Wagner Law has never been tested in Liberia and this study is the first of its kind to test the validity of whether the growth of national income facilitates the expansion of the spending envelop of national government in the Liberia economy.

The notion that as economic activities within a country increased, there is a proclivity for national government to increase its spending in order to match the increased in economic activities. This has come to be referred to as
Wagner's Law of increasing state activities.

The Law opines that there is a long run tendency for government spending to increase in relation to the growth of GDP [15]. Wagner's law presents three main explanations for national income to raise the government expenditure:

(i) When a country is on the industrialized period;

(ii) When the economic growth causes an increasing demand of public services; and

(iii) When government contribution for capital accumulation in which the private sector would not satisfy. 
Countries pursuing development and transformation usually give birth to the private sector involvement, providing services and goods which were otherwise provided by the public sector. This give rise to the expansion of the economy and hence creates the argument for the growth of the government spending to be redirected to other services, such as increased infrastructure development, the increased in the provision of security and the expansion of the government bureaucracy. This was what Wagner's envisage when he postulated his law.

\section{Literature Examination}

Wagner's law have been examined by several economists from different counties and there are mixed results from each country, based on the assumption used as well as the level of activities in those countries. Data from both developed and developing countries showed interesting results. The law has triggered diverse opinions in the domain of public finance. Firstly, it generates concerns on the practical forms for the empirical testing and analysis by which the results are to be interpreted. Secondly, when regressing the variables of interest in the law, it is often prudent to data that are annual time series with long span coverage in order to properly test this law [4]

Rowley and Tollison for example, argued that Wagner Law would exist by comparing it with comparative advantage industries of the country which is under government authority [12], hence, it can be said that the decreasing of comparative advantage will trigger the public expenditure-GDP ratio to be decreased [10].

Gatauwa also argued that the law seems to be cumbersome to analyze and test because it is unclear which econometric implements to use in testing the law and how to explain the results in terms of explaining the future [3].

Musgrave was also intrigued as to whether the expansion of the economy was referencing national income growth in terms of productivity or simply the overall level of growth of the public domain [8]. This confusion of Musgrave was clarified by Timm, when Timm conducted a holistic assessment of the law and concluded that Wagner may have had relative growth of the economy in mind [see 9 and 14]. However, there is a general agreement amongst economists that the law should be interpreted in line with predicting relative shares of the public sector vis a vis the general increase in per capita income growth [3].

Some examples of the test of the law conducted on developed countries showed mixed results:

Ram concluded a positive link between government spending and the growth of GDP for 115 countries over a 30 years period [11].

Tang, Tuck and Cheong tested link between GDP and government spending from 1960 to 1998 in Malaysia using annual times series data and concluded that there is no long run relationship amongst the two variables tested thus providing Wagner's law invalid for Malaysia [13].

Olomola ascertained both short and long run link between GDP and the growth of government spending covering a period of 31 years, thus validating Wagner's law for Nigeria [7].

\section{Analytical Framework, Data Specification and Methodology}

In any time series model, unit roots are important because it helps develop the model by checking for stationarity or non-stationarity in the variables in the model. Non stationarity in models creates problems such as spurious regression. In order to avoid such situation, unit roots tests become essential. In this paper, the Dickey Fuller (DF) unit roots test was applied to determine stationarity or nonstationarity of our model. There are several methods of applying the DF test. Whatever the method to apply, the null hypothesis $\phi=0$; which implies that there is a unit root and the variable is non-stationary. The alternative hypothesis is that $\phi<0$, which suggest that the time series is stationary. If we are to reject the null hypothesis that would mean that the random walk is a stationary time series with zero mean.

The results below showed the unit roots tests as developed by Dr. Imadeddin Almosabbeh. In the results below, all the variables, that is GDP and Government spending are nonstationary at levels. This therefore means that there exist unit roots in the variables. In order to resolve the issues of unit roots and to avoid spurious regression, the variables were first difference from their level form (I(0) to I(1). The Addins on the eviews 10 version was used as was developed by Dr. Imadeddin Almosabbeh from the college of Business and Economics, Qassim University, KSA.

Table 1. UNIT ROOT TEST RESULTS TABLE (ADF).

\begin{tabular}{|c|c|c|c|}
\hline \multicolumn{4}{|c|}{ Null Hypothesis: the variable has a unit root } \\
\hline & At Level & & \\
\hline \multirow{4}{*}{ With Constant } & & LNGDP & LNGE \\
\hline & t-Statistic & -1.2081 & -1.7099 \\
\hline & Prob. & 0.6638 & 0.4202 \\
\hline & & n0 & n0 \\
\hline \multirow[t]{3}{*}{ With Constant \& Trend } & t-Statistic & -1.7777 & -1.8893 \\
\hline & Prob. & 0.7003 & 0.6452 \\
\hline & & n0 & n0 \\
\hline \multirow[t]{4}{*}{ Without Constant \& Trend } & t-Statistic & 0.6896 & 0.3019 \\
\hline & Prob. & 0.8613 & 0.7692 \\
\hline & & n0 & n0 \\
\hline & At First D & & \\
\hline
\end{tabular}




\begin{tabular}{|c|c|c|c|}
\hline With Constant & $\begin{array}{l}\text { t-Statistic } \\
\text { Prob. }\end{array}$ & $\begin{array}{l}\text { d(LNGDP) } \\
-4.2007 \\
0.0017 \\
* * *\end{array}$ & $\begin{array}{l}\mathrm{d}(\mathrm{LNGE}) \\
-7.093 \\
0.0000 \\
* * *\end{array}$ \\
\hline With Constant \& Trend & $\begin{array}{l}\text { t-Statistic } \\
\text { Prob. }\end{array}$ & $\begin{array}{l}-4.1716 \\
0.0096 \\
* * *\end{array}$ & $\begin{array}{l}-7.028 \\
0.0000 \\
* * *\end{array}$ \\
\hline Without Constant \& Trend & $\begin{array}{l}\text { t-Statistic } \\
\text { Prob. }\end{array}$ & $\begin{array}{l}-4.157 \\
0.0001 \\
* * *\end{array}$ & $\begin{array}{l}-7.1386 \\
0.0000 \\
* * *\end{array}$ \\
\hline
\end{tabular}

a: $(*)$ Significant at the $10 \% ;(* *)$ Significant at the $5 \% ;(* * *)$ Significant at the $1 \%$ and (no) Not Significant

b: Lag Length based on SIC

c: Probability based on MacKinnon (1996) one-sided p-values.

Source: Eviews and computed by author, 2020

\subsection{Testing for Long Run Relationship Between the Variables: Johanssen Cointegration Test}

Testing for long run relationship between the growth of the economy and the growth of government expenditure in the model, the vector error correction based cointegration test developed by [5] and [6] which primarily depends on the first difference of the order $\mathrm{p}$ given as:

$$
\Delta \mathrm{Y}_{\mathrm{t}}=\lambda \mathrm{Y}_{\mathrm{t}-1}+\sum_{k=0}^{p=0} \quad \Upsilon_{\mathrm{i}} \Delta \mathrm{Y}_{\mathrm{t}-1}+\mathrm{Cx}_{\mathrm{t}}+\mu_{\mathrm{t}}
$$

Where $Y_{t}$ represents a non stationary vector of order 1 or first difference containing both GDP and government spending and $\mu_{\mathrm{t}}$ is the white noise.

The null hypothesis when conducting the [6] cointegration test is stated as:

$\mathrm{H}_{0}$ : No cointegrating equation

$\mathrm{H}_{1}: \mathrm{H}_{0}$ is untrue or there is cointegrating equation.

The first thing that must be considered when conducting a Johanssen cointegration test is all variables of interest should be $\mathrm{I}(0)$ form and not $\mathrm{I}(1)$ or their first difference. However, the work of [5] presented variables which were first differenced of the order $\mathrm{p}$ as reflected in the above equation. In this paper, the variables that were used, that is Government spending and GDP were logged transformed of the raw variables. The decision criteria include rejection of the null hypothesis that there is no long run relationship between the variables if the probability ( $p$-value) is less than or equal to the $5 \%$ critical value or rejection of the null hypothesis if the value of the Trace and Max statistics $>5 \%$ critical value.

The results below showed various methods of interpretations. If we are looking at the Trace statistics and critical value at $5 \%$, we can see that we will reject the null hypothesis that there is no cointegration between the variables because the Trace statistics of 17.2 is greater than the critical value at $5 \%$ of 17.25 and therefore we can conclude that there is long run relationship between the variables or there is cointegration between the variables. The Max- Eigen result showed the same result that the MaxEigen value is greater than the $5 \%$ critical value as shown on the table below.

Table 2. Cointegration Result.

\begin{tabular}{|c|c|c|c|c|}
\hline \multicolumn{5}{|c|}{ Unrestricted Cointegration Rank Test (Trace) } \\
\hline Hypothesized & & Trace & 0.05 & \\
\hline No. of CE(s) & Eigenvalue & Statistic & Critical Value & Prob.** \\
\hline None * & 0.282893 & 17.25886 & 15.49471 & 0.0269 \\
\hline At most 1 & 0.026667 & 1.297395 & 3.841466 & 0.2547 \\
\hline \multicolumn{5}{|c|}{ Trace test indicates 1 cointegrating eqn(s) at the 0.05 level } \\
\hline \multicolumn{5}{|c|}{ * denotes rejection of the hypothesis at the 0.05 level } \\
\hline \multicolumn{5}{|c|}{ **MacKinnon-Haug-Michelis (1999) p-values } \\
\hline \multicolumn{5}{|c|}{ Unrestricted Cointegration Rank Test (Maximum Eigenvalue) } \\
\hline Hypothesized & & Max-Eigen & 0.05 & \\
\hline No. of CE(s) & Eigenvalue & Statistic & Critical Value & Prob.** \\
\hline None * & 0.282893 & 15.96146 & 14.26460 & 0.0267 \\
\hline At most 1 & 0.026667 & 1.297395 & 3.841466 & 0.2547 \\
\hline \multicolumn{5}{|c|}{ Max-eigenvalue test indicates 1 cointegrating eqn(s) at the 0.05 level } \\
\hline \multicolumn{5}{|c|}{ * denotes rejection of the hypothesis at the 0.05 level } \\
\hline \multicolumn{5}{|c|}{ **MacKinnon-Haug-Michelis (1999) p-values } \\
\hline \multicolumn{5}{|c|}{ Unrestricted Cointegrating Coefficients (normalized by $b^{\prime *} \mathrm{~S} 11 * b=\mathrm{I}$ ): } \\
\hline LNGDP & LNGE & & & \\
\hline-1.92258 & 1.398917 & & & \\
\hline 2.292835 & -0.69143 & & & \\
\hline
\end{tabular}

Source: Eviews and computed by author, 2020 


\subsection{Vector Error Correction Model}

The next stage of our analysis is to test the system using error correction model since we have established the existence of long run relationship between the variables; that is if non stationary but $\mathrm{I}(1)$ series are showing the presence of long run relationship, we can now run vector error correction model to examine both short and long run dynamics of the series as indicated by Engle, Granger and Clive (1987). Convention error correction model for cointegrated series takes the form:

$$
\Delta \mathrm{Y}_{\mathrm{t}}=\beta_{0}+\sum_{k=0}^{n} \beta_{\mathrm{i}} \Delta \mathrm{y}_{\mathrm{t}-1}+\sum_{k=0}^{n} \Gamma_{\mathrm{i}} \Delta \mathrm{x}_{\mathrm{t}-1}+\varphi \mathrm{Z}_{\mathrm{t}-1}+\mu_{\mathrm{t}}
$$

Type equation here.

$$
\text { Where } \mathrm{Z}_{\mathrm{t}-1}=\mathrm{ECT}_{\mathrm{t}-1}=\mathrm{y}_{\mathrm{t}-1}-\beta_{0}-\beta_{1} \mathrm{X}_{\mathrm{t}-1} .
$$

And $\phi$ is the speed of adjustment which measures the speed at which $\mathrm{Y}$ returns to equilibrium.

The term error correction refers to the last period, the lag period, deviation from long run equilibrium (which is the error) influences the short run dynamics of the dependent variable.

\begin{tabular}{|c|c|c|}
\hline \multicolumn{3}{|l|}{ Standard errors in ( ) \& t-statistics in [ ] } \\
\hline Cointegrating Eq: & CointEq1 & \\
\hline $\operatorname{LNGDP}(-1)$ & 1.000000 & \\
\hline \multirow[t]{2}{*}{ LNGE(-1) } & -0.7276 & \\
\hline & {$[-9.07184]$} & \\
\hline $\mathrm{C}$ & -6.9244 & \\
\hline Error Correction: & D(LNGDP) & D(LNGE) \\
\hline \multirow{2}{*}{ CointEq1 } & $(0.04895)$ & $(0.20533)$ \\
\hline & [3.17514] & {$[3.48471]$} \\
\hline \multirow[t]{3}{*}{ D(LNGDP(-1)) } & 0.093744 & -0.3951 \\
\hline & $(0.15801)$ & $(0.66283)$ \\
\hline & {$[0.59327]$} & {$[-0.59614]$} \\
\hline \multirow[t]{3}{*}{ D(LNGDP(-2)) } & -0.0007 & 1.818956 \\
\hline & $(0.14401)$ & $(0.60409)$ \\
\hline & {$[-0.00460]$} & {$[3.01105]$} \\
\hline \multirow{2}{*}{ D(LNGE(-1)) } & $(0.03895)$ & $(0.16341)$ \\
\hline & {$[2.70175]$} & {$[0.74443]$} \\
\hline \multirow[t]{3}{*}{$\mathrm{D}(\mathrm{LNGE}(-2))$} & 0.114323 & 0.033467 \\
\hline & $(0.03637)$ & $(0.15256)$ \\
\hline & [3.14353] & {$[0.21938]$} \\
\hline \multirow[t]{3}{*}{$\mathrm{C}$} & 0.025588 & -0.0212 \\
\hline & $(0.02634)$ & $(0.11049)$ \\
\hline & {$[0.97150]$} & {$[-0.19225]$} \\
\hline R-squared & 0.428135 & 0.415491 \\
\hline Adj. R-squared & 0.360056 & 0.345907 \\
\hline Sum sq. resids & 1.306748 & 22.99450 \\
\hline S.E. equation & 0.176389 & 0.739924 \\
\hline F-statistic & 6.288790 & 5.971038 \\
\hline Log likelihood & 18.37877 & -50.446 \\
\hline Akaike AIC & -0.5158 & 2.351931 \\
\hline S.D. dependent & 0.220496 & 0.914887 \\
\hline Determinant resid covariance (dof adj.) & & 0.015013 \\
\hline Determinant resid covariance & & 0.011495 \\
\hline Log likelihood & & -29.037 \\
\hline Akaike information criterion & & 1.793218 \\
\hline Schwarz criterion & & 2.338985 \\
\hline Number of coefficients & & 14 \\
\hline
\end{tabular}

Table 3. Vector Error Correction Estimates.

Source: Eviews and computed by author, 2020

The error correction model as shown above says nothing about long run and short run relationship or causality. The reason for such is that the model itself does not have a pvalue. In order to obtain the p-value, we need to run the system equation. We need to do some diagnostics testing. Testing for higher order auto serial correlation, we will use the Breusch-Geoffred serial correlation LM test. the result below shows is therefore obtained. The rule is if the probability of the Chi square is below 0.05 or the $5 \%$, we will reject the null hypothesis of the presence of serial correlation. The result showed the existence of autoserial correlation since we cannot reject the null hypothesis of the presence of 
autoserial correlation. This means that there is autoserial correlation in the model and hence it has to be removed. We therefore proceed to using the lag of one of the variables in order to remove the autoserial correlation and after removing the autoserial correlation, we can now run the error correction model by looking for the p-values.

Table 4. Breusch-Godfrey Serial Correlation LM Test.

\begin{tabular}{llll}
\hline F-statistic & 17.18779 & Prob. F(2,47) & 0 \\
Obs*R-squared & 21.54399 & Prob. Chi-Square(2) & 0 \\
Variable & Coefficient & Std. Error & t-Statistic \\
LNGE & -0.03608 & 0.02877 & -1.25394 \\
C & 0.681645 & 0.540995 & 1.259984 \\
RESID(-1) & 0.626946 & 0.143822 & 4.359166 \\
RESID(-2) & 0.072232 & 0.151361 & 0.477218 \\
R-squared & 0.422431 & Mean dependent var & 0.2139 \\
Adjusted R-squared & 0.385565 & S.D. dependent var & 0.0001 \\
S.E. of regression & 0.335494 & Akaike info criterion & 0.6354 \\
Sum squared resid & 5.290146 & Schwarz criterion & -8.21 E-16 \\
Log likelihood & -14.5834 & Hannan-Quinn criter. & 0.428003 \\
F-statistic & 11.45853 & Durbin-Watson stat & 0.72876 \\
Prob(F-statistic) & 0.000009 & & 0.880276 \\
\hline
\end{tabular}

Source: Eviews and computed by author, 2020

Table 5. Vector Error Correction Estimates.

\begin{tabular}{|c|c|c|}
\hline \multicolumn{3}{|l|}{ Standard errors in ( ) \& t-statistics in [ ] } \\
\hline Cointegrating Eq: & CointEq1 & \\
\hline LNGDP(-1) & 1.000000 & \\
\hline \multirow[t]{3}{*}{ LNGE(-1) } & -0.7276 & \\
\hline & $(0.08021)$ & \\
\hline & {$[-9.07184]$} & \\
\hline $\mathrm{C}$ & -6.9244 & \\
\hline Error Correction: & D(LNGDP) & $\mathrm{D}(\mathrm{LNGE})$ \\
\hline \multirow[t]{3}{*}{ CointEq1 } & 0.155417 & 0.715513 \\
\hline & $(0.04895)$ & $(0.20533)$ \\
\hline & {$[3.17514]$} & {$[3.48471]$} \\
\hline \multirow[t]{3}{*}{ D(LNGDP(-1)) } & 0.093744 & -0.3951 \\
\hline & $(0.15801)$ & $(0.66283)$ \\
\hline & {$[0.59327]$} & {$[-0.59614]$} \\
\hline \multirow[t]{3}{*}{ D(LNGDP(-2)) } & -0.0007 & 1.818956 \\
\hline & $(0.14401)$ & $(0.60409)$ \\
\hline & {$[-0.00460]$} & {$[3.01105]$} \\
\hline \multirow[t]{3}{*}{ D(LNGE(-1)) } & 0.105244 & 0.121644 \\
\hline & $(0.03895)$ & $(0.16341)$ \\
\hline & {$[2.70175]$} & {$[0.74443]$} \\
\hline \multirow[t]{3}{*}{ D(LNGE(-2)) } & 0.114323 & 0.033467 \\
\hline & $(0.03637)$ & $(0.15256)$ \\
\hline & {$[3.14353]$} & {$[0.21938]$} \\
\hline \multirow[t]{3}{*}{$\mathrm{C}$} & 0.025588 & -0.0212 \\
\hline & $(0.02634)$ & $(0.11049)$ \\
\hline & {$[0.97150]$} & {$[-0.19225]$} \\
\hline R-squared & 0.428135 & 0.415491 \\
\hline Adj. R-squared & 0.360056 & 0.345907 \\
\hline Sum sq. resids & 1.306748 & 22.99450 \\
\hline S.E. equation & 0.176389 & 0.739924 \\
\hline F-statistic & 6.288790 & 5.971038 \\
\hline Log likelihood & 18.37877 & -50.446 \\
\hline Akaike AIC & -0.5158 & 2.351931 \\
\hline Schwarz SC & -0.2819 & 2.585831 \\
\hline Mean dependent & 0.043601 & 0.058534 \\
\hline S.D. dependent & 0.220496 & 0.914887 \\
\hline Determinant resid covariance (dof adj.) & & 0.015013 \\
\hline Determinant resid covariance & & 0.011495 \\
\hline Log likelihood & & -29.037 \\
\hline Akaike information criterion & & 1.793218 \\
\hline Schwarz criterion & & 2.338985 \\
\hline Number of coefficients & & 14 \\
\hline
\end{tabular}


Examining the model above, we can say that a $1 \%$ change in government spending will result in a $72.76 \%$ change in GDP. We can now run the system to determine the $\mathrm{p}$-values of the model: the result clearly shows that the process is not converging in the long run since the coefficient value (represented as c1) which by rule supposed to be negative is shown in this result to be positive. However if we are establishing if there is a long run relationship between the variables, we examine the coefficient of each of the variables.
For GDP, the targeted coefficient is c(1) and we can say that GDP do have a long run relationship since its probability value is less than $5 \%$. We can say the same of government spending whose coefficient is $\mathrm{c}(7)$. We can also say government spending do have a long run relationship in the model. From the results below, our interest lies in C(4) and $\mathrm{C}(5)$ which is basically whether government spending granger causes economic growth (GDP). This therefore suggest that Wagner's law is valid for the Liberian economy.

Table 6. System Equation.

\begin{tabular}{|c|c|c|c|c|}
\hline & Coefficient & Std. Error & t-Statistic & Prob. \\
\hline $\mathrm{C}(1)$ & 0.155416 & 0.048948 & 3.175128 & 0.0021 \\
\hline $\mathrm{C}(2)$ & 0.093746 & 0.158012 & 0.593285 & 0.5546 \\
\hline$C(3)$ & -0.000660 & 0.144009 & -0.004583 & 0.9964 \\
\hline $\mathrm{C}(5)$ & 0.114323 & 0.036368 & 3.143521 & 0.0023 \\
\hline$C(6)$ & 0.025588 & 0.026339 & 0.971491 & 0.3341 \\
\hline$C(7)$ & 0.715513 & 0.205329 & 3.484712 & 0.0008 \\
\hline $\mathrm{C}(9)$ & 1.818956 & 0.604094 & 3.011049 & 0.0034 \\
\hline $\mathrm{C}(10)$ & 0.121644 & 0.163406 & 0.744427 & 0.4587 \\
\hline $\mathrm{C}(11)$ & 0.033467 & 0.152557 & 0.219376 & 0.8269 \\
\hline $\mathrm{C}(12)$ & -0.021242 & 0.110488 & -0.192251 & 0.8480 \\
\hline Determinant residual covariance & & 0.011495 & & \\
\hline \multicolumn{5}{|l|}{ Equation: } \\
\hline \multicolumn{5}{|c|}{$\begin{array}{l}\mathrm{D}(\mathrm{LNGDP})=\mathrm{C}(1) *(\mathrm{LNGDP}(-1)-0.72762604595 * \mathrm{LNGE}(-1)-6.92439666092)+\mathrm{C}(2) * \mathrm{D}(\mathrm{LNGDP}(-1))+\mathrm{C}(3) * \mathrm{D}(\mathrm{LNGDP}(-2))+\mathrm{C}(4) * \mathrm{D}(\mathrm{LNGE}(-1))+ \\
\mathrm{C}(5) * \mathrm{D}(\mathrm{LNGE}(-2))+\mathrm{C}(6)\end{array}$} \\
\hline \multicolumn{5}{|c|}{ Observations: 48} \\
\hline R-squared & 0.428135 & Mean dependent var & & 0.043601 \\
\hline Adjusted R-squared & 0.360056 & S.D. dependent var & & 0.220496 \\
\hline S.E. of regression & 0.176389 & Sum squared resid & & 1.306748 \\
\hline Durbin-Watson stat & 2.187745 & & & \\
\hline \multicolumn{5}{|l|}{ Equation: } \\
\hline \multirow{2}{*}{\multicolumn{5}{|c|}{$\begin{array}{l}\mathrm{D}(\mathrm{LNGE})=\mathrm{C}(7) *(\mathrm{LNGDP}(-1)-0.72762604595 * \mathrm{LNGE}(-1)-6.92439666092)+\mathrm{C}(8) * \mathrm{D}(\mathrm{LNGDP}(-1))+\mathrm{C}(9) * \mathrm{D}(\mathrm{LNGDP}(-2))+\mathrm{C}(10) * \mathrm{D}(\mathrm{LNGE}(-1))+ \\
\mathrm{C}(11) * \mathrm{D}(\mathrm{LNGE}(-2))+\mathrm{C}(12)\end{array}$}} \\
\hline & & & & \\
\hline R-squared & 0.415491 & Mean dependent var & & 0.058534 \\
\hline Adjusted R-squared & 0.345907 & S.D. dependent var & & 0.914887 \\
\hline S.E. of regression & 0.739924 & Sum squared resid & & 22.99450 \\
\hline Durbin-Watson stat & 1.879190 & & & \\
\hline
\end{tabular}

Source: eviews and computed by author, 2020

We will use the Wald test to determine whether economic growth granger causes government spending. The result below show the Wald test result: the result showed from the Wald test that we can reject the null hypothesis that economic growth granger causes government spending since the probability value is below the $5 \%$. Below is the result of the Wald test shown.

Table 7. Wald Test.

\begin{tabular}{lll}
\hline Test Statistic $\quad$ Value & df & Probability \\
Chi-square $\quad 12.32312$ & 2 & 0.0021 \\
Null Hypothesis: $\mathrm{C}(4)=\mathrm{C}(5)=0$ & & \\
Null Hypothesis Summary: & & \\
Normalized Restriction $(=0)$ & Value & Std. Err. \\
$\mathrm{C}(4)$ & 0.105243 & 0.038954 \\
$\mathrm{C}(5)$ & 0.114323 & 0.036368 \\
Restrictions are linear in coefficients. & \\
\hline
\end{tabular}

Source: eviews and computed by author, 2020

\section{Conclusion}

Wagner's law has never been tested before in the Liberian economy and this paper is the first of its kind to ever test the validity of the law for the Liberian case. Over the years, there has been fluctuations in the growth of the Liberian economy which has given rise to the expansion of the revenue stream, thus increasing the spending pattern of national government in Liberia. This paper investigated whether or not such growth of the macroeconomy was the economic justification of the growth of the spending pattern of government.

From the regression conducted on bivariate model, using the transformed form of the log of GDP and the log of government spending, we can conclude that indeed economic growth do influence government spending in the Liberian economy and therefore proves the validity of Wagner's law for the Liberian economy. 


\section{References}

[1] Abizadeh, S., Yousefi, M. (1998), “An Empirical Aanalysis of South Korea's Economic Development and Public Expenditures Growth." Journal of Socio-economics, Vol. 27, No. 6, pp. 687-701.

[2] Chletos, M., Kollias, C. (1997), "Testing Wagner's Law Using Disaggregated Public Expenditure Data in the Case of Greece: 1958-1993." Applied Economics, Vol. 29, pp. 371-377.

[3] Gatauwa, J. (2014). The 2008 Global Economic Crisis and Public Expenditure: A Critical Review of the Literature. Advances in Management \& Applied Economics, vol. 4, no. 2.

[4] Henrekson, M. (1993) Wagner's law: A spurious relationship? Public Finance, 49 (2).

[5] Johansen, S., \& Juselius, K. (1990). Maximum likelihood estimation and inference on cointegration with applications to the demand for money. Oxford Bulletin of Economics and Statistics, 52, 169-210.

[6] Johansen, S. (1988) Statistical analysis of cointegration vectors, journal of economic dynamics and control, vol. 12, no. $2-3$.

[7] Olomola, P. A. (2004) "Cointegration analysis-causality testing and Wagner's law: the case of Nigeria," Journal of Social and Economic Development, vol. 6, no. 1.

[8] Musgrave, R. (1969) Theories of fiscal federalism. Public finance vol. 24, issue 4.

[9] Musgrave, R. A., (1969). Fiscal System. Yale University Press, New Haven.

[10] Peacock, A. and Scott, A. (2000) the curious attraction of Wagner's law.

[11] Ram, R., 1986, Government size and economic growth: a new framework and some evidence from cross-section and timeseries data, The American Economic Review 76, 191-203.

[12] Rowley, C. K. and Tollison, R. D. (1994) Peacock and Wiseman on the growth of Public Expenditure. Public Choice, Vol. 78, pp. 125-128.

[13] Tang, T. C., Tuck, L. Cheong, H. (2001) Testing the relationship between government expenditure and national income in Malaysia. Analisis, 8 (1\&2). pp. 37-51. ISSN 01278983.

[14] Timm, H. (1961) 'Das Gesetz der wachsenden staatsausgaben' Finanz Archiv/ Public finance analysis, 21 (2), pp. 201-247.

[15] Wagner, A. (1883). Classics in Theory of Public Finance. Macmillan, London. 